\title{
Impact of Climate Change on Livestock Production
}

\author{
A. Koirala ${ }^{1}$ and P. Bhandari ${ }^{2}$ \\ ${ }^{1}$ Building Resilience to Climate related Hazards Project, (Agriculture Management Information \\ System), Ministry of Agricultural and Livestock Development. \\ ${ }^{2}$ Postgraduate Campus, Institute of Agriculture and Animal Science, Kirtipur.
}

\begin{abstract}
Climate change is one of the global challenges of this century. There is increase in large number of climate related events. Livestock sector has also been affected by changing climate due to which there is increasedloss of livestock assets and several other indirect losses. Some of the effects of climate changein livestock include thermal and cold stress, increased diseases incidences and decrease in the feed, fodder and water availability. This results in decreased animal production and productivity. The paper mainly reviews the impacts of climate change on livestock production.
\end{abstract}

Keywords: Climate change, Livestock, Livestock production

\section{INTRODUCTION}

A long-term shift in temperature, radiation, wind and rainfall of a place in a long term of time is climate. It is the change in climatic conditions over time due to either anthropogenic or nature induced causes, which remains for decades or longer and shows distinct variations in its mean (IPCC 2007). The issue of events caused by climate change is seen frequently nowadays. It is causing huge loss of lives and economy of various countries. As greenhouse gas is increasing in the atmosphere leading to increase in the temperature of earth, there is a prediction that there will be aincrease in temperature by $1.5^{\circ} \mathrm{C}$ to $2^{\circ} \mathrm{C}$ in future may cause loss of 20 to 30 percentages of animal and plant species (Thronton, 2010).This shows that to survive in future changing climate, plant and animal species need to alter their behavior and distribution patterns and get acclimatized to changing climate. Direct and indirect effects of temperature, humidity, rainfall and other climate factors influence animal performance: growth, milk production, wool production and reproduction (Houghton et.al., 2001).

Livestock system is one of the major sources of nutrition to the increasing population of the world. Human populations largely depend on animals and animal products like milk, meat, eggs, fibers, wool, and feather.Animals are also used for transport, draft and their manure.Livestock production is adversely affected by various events of extreme climatic conditions. This paper focuses in the effect of climate change on livestock production.

\section{Climate Change}

Climate change is a phenomenon due to emissions of greenhouse gases from fuel combustion, deforestation, urbanization and industrialization (Upreti, 1999) resulting variations in solar energy, temperature and precipitation. It is a real threat to the lives in the world that largely 
affects water resources, agriculture, livestock, coastal regions, freshwater habitats, vegetation, forests, melting of snow-covered mountains and increase in climatic events such as landslide, desertification and flood. Around the world the three major components of climate change already evident and escalating in magnitude and significance are; Warming, altered patterns of precipitation and increased incidence of extreme climatic events.

\section{Effect of Climate Change on Livestock}

The effect of climate change is found to be real and is affecting livestock population in many ways. Climate change is expected to cause increase in weather-related disasters and extreme weather events, such as droughts, heat waves, storms, desertification, and increases in insect infestations (Khanal, 2010). Long-term changes in climate will affect the future of all animals including those in oceans, on farms, in forests, in wilderness areas, and in our homes (Khanal, 2010). Warmer and wetter weather (particularly warmer winters due to climate change) will increase the risk and occurrence of animal diseases, as certain species who serve as disease vectors, such as biting flies and ticks, are more likely to survive year-round. At higher temperature, numerous diseases display greater virulence. As a result of climate change the environment becomes favorable for the disease agent (bacteria, virus, etc.) and the host will become susceptible easily. The epidemiological triad between agent, host and environment becomes imbalanced and - different diseases which were not present in -an ecological region may be seen, and certain existing parasitic diseases may also become more prevalent, or their geographical range may spread, if rainfall increases.

Increased temperature may cause thermal stress in terrestrial and aquatic animals, leading to reduced growth, sub optimal behaviors, decrease productivity and reduced immune competence of the animals. Higher temperatures tend to reduce animal feed intake and lower feed conversion rates (Rowlinson, 2008) and extra investment cost to keep animal warm or cool during climatic extremes is forecasted to increase. Unusual climatic changes and variability such as rising temperature, irregular monsoon, precipitation and erratic rainfall patterns have led to loss of large number livestock species ultimately affecting the income and food security of marginalized people. Climate change can be expected to have several impacts on forage, feed crops, grazing system, and emergence of unpalatable forage species in the rangeland and decrease the byproducts of agriculture and forage causing scarcity of fodder and forage for livestock.

\section{Climate Influence on Livestock Productivity}

The influence of climate change on livestock productivity is categorized on following headings.

\section{Milk Production}

High production animals are highly influencedby heat stress (Martello et.al.,2010). The threshold level of temperature humidity index (THI) for the high milk yielding cow is around THI 72 in tropical and subtropical climates. However, recent studies on THI in temperate climate emphasized that the THI lower than 68 is suitable for cattle performance (Gauly et.al., 2013). Early heat stress signs in dairy cows include panting and sweating and longer standing. These factors lead to cows failing to eat as much as usual. 
Heat stress decreases the quality and composition of milk. This can result in a rapid decline in milk yield up to $40 \%$. Heat stress increase body temperature and affect the fat synthesis in mammary gland and components like fat (\%), solid-non-fat, protein, casein and lactose content is altered. Somatic cell count is also increased causing reduction in the quality of milk. Further, heat stress can also cause imbalance in the levels of prolactin, thyroid hormones, glucocorticoid, growth hormone, estrogen, progesterone and oxytocin which ultimately affects the milk production (Prathap et.al., 2017).

Heat stress increase udder temperature and can cause mastitis in dairy cows. In addition, heat stress during dry period might trigger mammary gland involution accompanied with apoptosis and autophagy and decreased amount of mammary epithelial cells can ultimately cause decline in milk yield (Prathap et.al., 2017).

As temperature rises above $35^{\circ} \mathrm{C}$ stress response systems is activated and there is reduced feed intake declining the milk synthesis (Wheelock et.al., 2010). Moreover, maintenance energy requirement is also increased by $30 \%$ in heat stressed dairy animal. Energy intake will not be enough to cover the daily requirements and milk production. This results in negative energy balance is created deteriorate health condition of the animal (West et.al, 2003). A reduction in dry matter intake by $0.85 \mathrm{~kg}$ with every $1^{\circ} \mathrm{C}$ rise in air temperature decreases milk production approximately by $36 \%$ (Rhoads et.al., 2009).

\section{Growth Performances}

Exposure of animals to hot or cold stress reduces growth and feed efficiency (Ames et.al., 1980). Cold climate during winter causes metabolic acclimatization, resulting in decreased animal performance and production efficiency (Young, 1981; Birkelo et.al., 1991). Cold stress increased concentrations of plasma corticosteroids (Alvarez and Johnson, 1973) and circulating nonesterified fatty acid (NEFA) concentrations (Broucek et.al., 1987; Nonnecke et.al., 2009).Heat stress has an effect on the uterine environment reducing the total embryo cell number and placentome size and small sized calf are born. Temperatures ranging between $15^{\circ} \mathrm{C}$ and $29^{\circ} \mathrm{C}$ seem to have no effect on growth performance. High ambient temperature decreases the anabolic activity and increase in tissue catabolism (Marai et.al., 2007). Reduced anabolism activity decreases voluntary feed intake and increase tissue catabolism causes fat depots resulting in adverse effect in growth performance.

\section{Reproductive Performance}

Reproductive performances of livestock are vulnerable to climate change. It has adverse effect in both female and male reproductive system. Heat stress reduces the length and intensity of oestrous cycle and besides increases incidence of anestrus and silent heat in animals (Kadokawa et.al., 2012). There is increase in adrenocorticotropic hormone and cortisol secretion (Singh et.al., 2013), resulting in blockage of estradiol-induced sexual behavior (Hein, K.G. and Allrich, R.D. 1992). When the body temperature exceeds $40^{\circ} \mathrm{C}$, follicles suffer damage and become nonviable (Roth et.al., 2000). When a female goat is exposed to $36.8^{\circ} \mathrm{C}$ temperature and $70 \%$ relative humidity for 48 hours, follicular growth upto ovulation is suppressed, accompanied by decreased LH receptor level and follicular estradiol synthesis activity. Infertility is seen in hightemperature as there is increase secretion of endometrial PGF-2 $\alpha$ (Bilby et.al., 2008).Conception 
rates decrease and reaches only $10-20 \%$ compared to $40 \%$ to $60 \%$ in cooler months (Cavestany et.al., 1985).

Heat stress causes embryonic death by interfering with protein synthesis, oxidative cell damage reducing interferon- tau production for signaling pregnancy recognition and expression of stressrelated genes associated with apoptosis (Hansen, P.J. 2009). Embryos subjected to high temperatures in vitro or in vivo until day 7 of development phase as blastocyst lowers pregnancy at day 30 and increases embryonic loss on 42 days of gestation (Cardozo et.al., 2006).

Increased testicular temperature in bull from thermal stress could change the quality of the semen and alter the biochemical composition leading to infertility problems. There is a change in testicular volume, hormonal profiles, sexual behavior and semen quality that affect the reproductive performance of males (Balic et.al., 2012).

\section{CONCLUSION}

The global demand of animal and animal products is increasing with the increasing human population. However, climate change is causing negative effects in the animal production and productivity. Climate extreme hazards are increasing causing huge loss of livestock assets and there is decrease in the feed, fodder and water availability for the animals, and increase in thermal and cold stress, diseases resulting in the decrease in animal production. Proper breeding strategies should be identified so that animal become tolerant to heat and cold and survive (Hoffmann, 2008). Identifying and strengthening local breeds adapted to local climatic stress and feed sources would be one of the options to mitigate the negative effects of climate change in livestock. Likewise, early warning systems and forecasting system for livestock diseases should be developed.

\section{REFERENCES}

Alvarez, M. B and H. D. Johns on. (1973). Environmental heatexposure on cattle plasma catecholamine and glucocorticoids. Journal of Dairy Science, 56:189-194

Balic I M, Milinkovic-Tur S, Samardzija M and Vince S. (2012). Effect of age and environmental factors on semen quality, glutathione peroxidase activity and oxidative parameters in Simmental bulls. Theriogenology, 78 (2): 423-431.

Birkelo CP, Johnson DE, Phetteplace HP. (1991). Maintenance requirements of beef cattle as affected by season on different planes of nutrition. Journal of Animal Science, 69:1214-1222.

Bilby T.R, Baumgard L.H, Collier R.J, Zimbelman R.B, Rhoads M.L. (2008). Heat stress effects on fertility: Consequences and possible solutions. The Proceedings of the 2008 South Western Nutritional Conference.

Broucek J, Kovalcik K, Gajdosik D, Brestensky, V. (1987). The effect of extreme ambient temperatures on haematological and biochemical indicators in heifers. Journal of Veterinary Medicine, 32:259-268.

Cardozo J.A, Fernández-Juan M, Forcada F, Abecia A, Muiño-Blanco T and Cebrián-Pérez, J.A. (2006). Monthly variations in ovine seminal plasma proteins analyzed by twodimensional polyacrylamide gel electrophoresis. Theriogenology, 66 (4): 841-850.

Cavestany D, El-Whishy, A.B and Foot, R.H. (1985). Effect of season and high environmental temperature on fertility of Holstein cattle. Journal of Dairy Science, 68 (6): 1471-1478. 
Gauly M, Bollwein H, Breves G, Brugemann K, Danicke S, Das G, Demeler J, Hansen H, Isselstein J, Knnig S, Loholter M, Martinsohn M, Meyer U, Potthoff M, Sanker C, Schroder B, Wrage N, Meibaum B. (2013). Future consequences and challenges for dairy cow production systems arising from climate change in Central Europe. Animal, 7:843-859

Hansen P.J. (2009). Effects of heat stress on mammalian reproduction. Philosophical Transactions of the Royal Society B: Biological, 364:3341-3350.

Hein K.G and Allrich, R.D. (1992). Influence of exogenous adrenocorticotropic hormone on estrous behavior in cattle. Journal of Animal Science, 70 (1): 243-247.

Hounghton J.T, Ding, Y., Griggs, D.J., Noguer, M., van der Linden, P.J., Dai, X., Maskell, K., and Johnson, C.A. (2001). Climate Change: The Scientific Basis. Contribution of Working Group I to the Third Assessment Report of the Intergovernmental Panel on Climate Change (Cambridge University Press) New York.

IPCC Intergovernmental Panel on Climate Change 2007 Climate Change 2007: impacts, adaptation and vulnerability. Summary for policy makers. Available at: www.ipcc.cg/SPM13apr07.pdf (accessed 3 February 2019)

Kadokawa H, Sakatani, M., and Hansen, P.J. (2012). Perspectives on improvement of reproduction in cattle during heat stress in a future Japan. Animal Science Journal,83 (6): 439-445.

Khanal, D.R., S.P. Shrestha, and U.M. Singh (2010). "Vulnerability of livestock to disease in relation to climate change." In Proceedings of the Workshop on Climate Change: Livestock Sector Vulnerability and Adaptation Nepal. Consultative Technical Workshop, October 28 and 29, 2010, Lalitpur, Nepal.

Marai I.F.M, El-Darawany A.A., Fadiel, A and Abdel-Hafez, M.A.M. (2007). Physiological traits as Affected by Heat Stress in Sheep-A Review," Small Ruminant Research,71:1-12.

Martello L.S, Junior, H.S., Silva, S.L and Balieiro, J.C.C. (2010). Alternative body sites for heat stress measurement in milking cows under tropical conditions and their relationship to the thermal discomfort of the animals. International Journal of Biometeorology,54: $647-652$.

Nonnecke B.J, Foote, M.R., Miller, B.L., Fowler, M., Johnson, T.E., Horst, R.L (2009). Effects of chronic environmental cold on growth, health, and select metabolic and immunologic responses of preruminant calves. Journal of Dairy Science, 92:6134 6143.

Prathap P, Archana, P.R.., Joy, A., Veerasamy, S., Krishnan, G., Bagath, M., Manimaran, V. (2017). Heat Stress and Dairy Cow: Impact on Both Milk Yield and Composition. International Journal of Dairy Science, 12: 1-11.

Rhoads R.P, Baumgard, L.H, Suagee, J.K and Sanders, S.R. (2013). Nutritional interventions to alleviate the negative consequences of heat stress. Advances in Nutrition, 4 (3): 267 276.

Roth Z, Meidan, R., Braw-Tal, R. and Wolfenson, D. (2000). Immediate and delayed effects of heat stress on follicular development and its association with plasma FSH and inhibin concentration in cows. Journal of Reproduction and Fertility, 120 (1): 83-90.

Rowlinson, P. (2008). Adapting livestock production systems to climate change - temperate zones. Livestock and global change. Proceedings of an international conference, Hammamet, Tunisia. Cambridge, UK, Cambridge University Press 61-63. 
Singh M, Chaudhari, B.K., Singh, J.K., Singh, A.K and Maurya, P.K. (2013). Effects of thermal load on buffalo reproductive performance during summer season. Journal of Biological Sciences 1 (1): 1-8.

Thornton, K. P, and Gerber, P. (2010). Climate change and the growth of livestock sector in developing countries: Mitigation and adaptation strategies to global change. International Journal, 5: 169-184.

Upreti, D.C. (1999). "Rising Atmospheric CO2 and Crop Response." SASCOM Scientific Report, $1-8$.

West J.W. (2003). Effects of heat-stress on production in dairy cattle. Journal of Dairy Science, 86 (6): 2131-2144.

Wheelock J.B, Rhoads, R.P., Van Baale, M.J., Sanders, S.R and Baumgard, L.H. (2010). Effect of heat stress on energetic metabolism in lactating Holstein cows. Journal of Dairy Science, 93 (2): 644-655.

Young B.A. (1981). Cold stress as it affects animal production. Journal of Animal Science, 52:154-163. 